\title{
How Student Reflections Have Guided the Evolution of a Mechanical Engineering Capstone Design Course
}

\author{
H.F. Machiel Van der Loos, Antony Hodgson, Jon Mikkelsen, Markus Fengler \\ Department of Mechanical Engineering, University of British Columbia \\ $<$ vdl, ahodgson, mikk, mfengler $>$ @mech.ubc.ca
}

\begin{abstract}
To provide for professional growth of students and to gain deeper insight into student engagement in the University of British Columbia MECH Capstone Design Project Course, the teaching team has deployed an open-ended reflection opportunity over the past 6 years as an adjunct to the required teaching evaluations. Three years of year-end questionnaires and three years of bi-monthly instructor-led reflection sessions form the datasets. Although the two formats are fundamentally different, the quality of the responses provides evidence of high student awareness of their own learning process and a desire to be a meaningful contributor in the conversation on course improvement.
\end{abstract}

Keywords: Design Learning, Reflective Practice, Capstone Project Course

\section{INTRODUCTION}

The value of reflection as a powerful component of successful, lifelong learning has long been recognized [1]. Numerous theories and models of learning focus on the cognitive links (and loops) involving action and reflection [e.g., 2] for students and practitioners of a particular expertise. Reflection is especially useful as a knowledge integration and internalization tool in group/team activities that are multi-faceted, such as in community service learning [3], and open-ended, such as real-world design projects [4].

In this paper, we present how we have integrated themed, reflection activities into a Capstone design course over 6 years, we illustrate recurring and hot-button topics, and we discuss how our responses to student concerns have been received over time.

\section{METHODOLOGY}

From 2007 to 2009, student reflections were solicited in the form of a written, anonymous teaching evaluation at the end of the course that included topics specific to project-based learning: e.g., resource availability, value of mentors, usefulness of supervisors, effectiveness of liaisons, lecture relevance, appropriateness of budget. In subsequent years, the paper-based evaluation was replaced with a campus-wide, standardized, on-line teaching evaluation that did not touch on the project- based aspects of the course. Hence, a second assessment process was developed to cover many of the same topics in a different format: bimonthly, themed, 60-minute group sessions led in a "café scientifique" [5] format with two instructors and 20-40 students. The themes were chosen as follows:

October: Project selection and start-up: what would you have done differently?

December: Focus on benchmarking, conceptualization, documentation requirements, innovation

February: Value of early prototyping; design process

April: Team dynamics

Since each MECH student cohort has approximately 120 students, 3-4 simultaneous sessions were held each time. All data were transcribed from flip-chart pages and instructor notes. Comments were organized by major themes and in positive and negative categories.

\section{RESULTS AND DISCUSSION}

Table I presents major themes and paraphrased highfrequency comments found in both the paper-based evaluations and the reflection sessions.

Table I. The primary topics and typical responses.

\begin{tabular}{|c|c|c|}
\hline $\begin{array}{l}\text { Design } \\
\text { Topic }\end{array}$ & $\begin{array}{l}\text { Positive } \\
\text { Comments }\end{array}$ & $\begin{array}{l}\text { Negative } \\
\text { Comments }\end{array}$ \\
\hline $\begin{array}{l}\text { Project } \\
\text { selection and } \\
\text { team-formation }\end{array}$ & $\begin{array}{l}\text { Breadth of topics } \\
\text { across } \\
\text { specializations }\end{array}$ & $\begin{array}{l}\text { Hard to judge } \\
\text { projects from the } \\
\text { Abstracts }\end{array}$ \\
\hline $\begin{array}{l}\text { The design } \\
\text { process and } \\
\text { key activities }\end{array}$ & $\begin{array}{l}\text { Pace keeps } \\
\text { teams on-track; } \\
\text { iterative prototyp- } \\
\text { ing essential }\end{array}$ & $\begin{array}{l}\text { Some steps irrele- } \\
\text { vant; access to } \\
\text { shop resources an } \\
\text { issue at the end }\end{array}$ \\
\hline $\begin{array}{l}\text { The value of } \\
\text { the docu- } \\
\text { mentation } \\
\text { components }\end{array}$ & $\begin{array}{l}\text { Structure } \\
\text { provides } \\
\text { framework for } \\
\text { deliverables }\end{array}$ & $\begin{array}{l}\text { Relative weighting } \\
\text { may not fit with } \\
\text { project; takes time } \\
\text { from prototyping }\end{array}$ \\
\hline $\begin{array}{l}\text { The effective- } \\
\text { ness of the } \\
\text { client, faculty } \\
\text { supervisor and } \\
\text { mentor }\end{array}$ & $\begin{array}{l}\text { The responsive- } \\
\text { ness of the client } \\
\text { is critical to } \\
\text { success }\end{array}$ & $\begin{array}{l}\text { When a client } \\
\text { changes the } \\
\text { scope in mid- } \\
\text { project, it causes } \\
\text { setbacks }\end{array}$ \\
\hline $\begin{array}{l}\text { The role of } \\
\text { team dynamics } \\
\text { in project } \\
\text { outcome }\end{array}$ & $\begin{array}{l}\text { Allocate team } \\
\text { roles early. Work } \\
\text { to students' } \\
\text { strengths }\end{array}$ & $\begin{array}{l}\text { Everyone has to } \\
\text { pull together to } \\
\text { maximize } \\
\text { efficiency }\end{array}$ \\
\hline
\end{tabular}


The listing of both positive and negative comments followed by discussion allowed students to see issues from wider perspectives and in many cases, corrected misconceptions. In other cases, it brought a deeper understanding of the common areas of trouble, reinforcing the students' awareness of the prominence of certain general and persistent problems faced by designers.

In the group reflection sessions, instructors tended to divide their responses to legitimate student criticisms into three categories:

1) in the case of suggestions for improvement beyond instructor control, provide clarification for the rationale of the current status;

2) for short-term fix requests, add to a to-do list and feedback to the class 2 weeks later; and

3) with long-term impact suggestions, collect input for possible action in subsequent years.

The first lecture of each year has included several slides to list improvements from the previous year and a "Top-10" list of reflections from previous years' students. All collated data from previous years' sessions are posted on the internal course website.

\section{CONCLUSIONS}

The reflection sessions provide an open forum to air gripes and to allow teams - which can be quite insular to realize that in some cases, their problems are shared by others and in other cases, they learn that their gripes are due to misconceptions. The safe environment (40 students; 2 instructors) is conducive to iterative and collective elaboration of difficult issues. While the reflections are shared among all students, their formulation and communication deepen each student's personal awareness and understanding of the learning process. The open discussion of issues perceived by the students helps to foster better understanding as well as provides effective feedback to instructors for iterative course improvement.

\section{Acknowledgements}

The authors would like to thank the past six years of fourth-year undergraduate students in Mechanical Engineering at UBC for their thoughtful input and engagement in the reflective practice that is such a central aspect of the department's Capstone Design Course.

\section{References}

[1] Schön, D. (1983) The Reflective Practitioner, How Professionals Think In Action, Basic Books.

[2] Argyris, M. and Schön, D. (1974) Theory in Practice. Increasing Professional Effectiveness, San Francisco: Jossey-Bass.

[3] Kolb, A.Y.; Kolb, D.A. (2005). Learning Styles and Learning Spaces: Enhancing experiential learning in higher education. Academy of Management Learning \& Education 4 (2): 193-212.

[4] Adams, R.S., Turns, J. Atman, C.J. (2003). Educating effective engineering designers: The role of reflective practice, Design Studies, Special Issue on Designing in Context, vol. 24, no. 3, pp. 275-294.

[5] http://www.cafescientifique.org/ (retrieved May 3, 2013) 